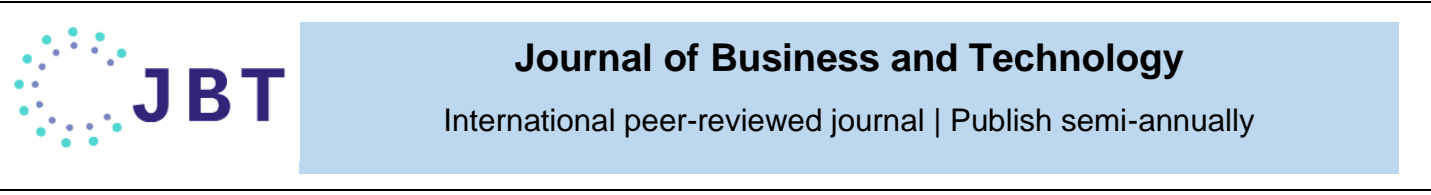

\section{Value Co-Creation and Co-Destruction in Online Education during the Covid19 Pandemic: Special reference to Sri Lankan State Sector Universities}

\author{
Karunathilake R.L.P. ${ }^{*}$, Galdolage B.S. ${ }^{2}$ \\ 12 Department of Marketing Management, University of Sri Jayewardenepura, Sri Lanka. \\ *Corresponding Author: lasithakarunathilake@gmail.com
}

\begin{abstract}
Covid-19 pandemic hit all aspects of individuals' lives in the whole globe including Sri Lanka and made mega changes in every person's day-to-day life. People had to limit travelling, thus services which used to provide at physical interfaces with direct face-to-face interactions had to search new options in delivering their services. Education sector, including higher education in Sri Lanka had to move from on-campus classroom-based teaching to new modes of delivering academic programs via remote basis. This new normal is challenging for both the academics and the students due to lack of experience and unequal distribution of facilities which inhibit equal value creation in education. Since this phenomenon is new, scholarly attention has not been received adequately. Therefore, this study aims to explore the value co-creation and co-destruction in online education in state sector universities in Sri Lanka.
\end{abstract}

The primary data were collected via semi-structured interviews from fifty university undergraduates representing different universities and geographic locations in Sri Lanka. They were encouraged to freely talk about their experience in online education. The study found nine key factors and reclassified them into four main themes as 'resources availability, commitment, interaction, and personal and domestic conditions' which bring value co-creation to some respondents while the same would destroy the value for some other students in gaining education. The findings would be helpful to the government, policy makers, academics, and students to enhance the collaborative value creation in distance education.

Keywords: Distance education, Online education, Online learning, Value co-creation, Value codestruction, Universities.

\section{INTRODUCTION}

The impact of the Covid 19 is not only to the health and economic aspects of a country. Education is also largely impacted by this pandemic. The schools and universities all around the world happened to shut the doors for students prohibiting physical presence. However, finding alternatives to continue education, many academic institutes moved from traditional mode of teaching to online based education undertaken remotely on digital platforms (Anusudha and Krishnendu, 2021).

Online education is not a surprise to the developed countries. Even before the COVID-
19, many developed countries had used online education with a high adoption, whereas in 2019 it has been invested US $\$ 18.66$ billion for online education and projected to reach $\$ 350$ billion by 2025 (GlobeNewswire, 2021). However, the education system of many developing countries was limited to traditional classroom-based teaching and learning practices. Therefore, adopting an online based teaching and learning environment became a significant challenge for many developing countries, including Sri Lanka (Khlaif et al., 2021). 
ISSN 2738-2028 (Online) | Vol. 5 | No. 2 | 2021 July

Sri Lankan higher education consists of sixteen state sector universities which were established under the authority of the University Grants Commission (University Grants Commission, 2021). Apart from those, the private sector is also making a significant contribution to higher education in the current context. However, both the government and private sector mainly used to provide oncampus based education where the students and teachers meet at university premises.

Though using online based technologies is a common practice in developed context, Sri Lankan universities had not even planned to achieve such a status in near future (Erandi et al., 2020). Adoption to online education was a forceful action of Covid19 pandemic, rather than a natural movement of advances in the education system. Though Sri Lanka is ranked as an upper middle income country (Central Bank of Sri Lanka, 2020), delivery modes of education, particularly online based education system has not been developed up to that level when compared to the other upper middleincome countries.

Education is a collaborative process where the active involvement of the teacher and the student is essential for a fruitful outcome. In classroom-based teaching methods, face -toface rich interactions take place among academics and students which result in high levels of collaborative value creation. In such an approach, students get many opportunities to engage in individual/group activities, problem-solving activities, construct their knowledge, work with peers, and reflect on the learning process. Such practices allow richer learning opportunities and deeper exploration of the content during in-class learning (Blau and Shamir-Inbal, 2017).

However, in online based teaching methods teacher-student interaction takes place screento-screen. Further, in developing countries, mainly due to non-availability of resources or not equally distributed available resources, while some students easily adhere to this new normal and create value (value co-creation) some others suffer their academic life resulting in value co-destructions (Failures in the collaborative value creation process). There can be many reasons which improve or hinder collaborative value creation process in online based education, which are unexplored yet.

This study broadly aims at understanding students' view about distance education conduct during the Covid 19 pandemic period. While it intends to recognize reasons for successes and failures in online education which enhance or diminish the 'value in use' of higher education. Therefore, this study develops its main objectives as,

RO1: To explore why and how value cocreation takes place in distance education (online based) among state sector university undergraduates in Sri Lanka during the Covid 19 Pandemic.

RO2: To explore the reasons for value codestruction in distance education (on-line based) among state sector university undergraduates in Sri Lanka during the Covid 19 Pandemic.

Next, the paper presents the conceptual background of the study, subsequently, the methodology of the study is elaborated before providing the finding and discussion. Third, theoretical and practical contributions are discussed along with the limitations and future research directions.

\section{LITERATURE REVIEW}

The literature review is focused on assessing existing literature related to online based teaching, evolution of distance learning, student interaction and value co-creation as well as co-destruction in online based education for university undergraduates.

\section{Distance Learning and Online Based Education}

The world online-based learning can be classified in to five eras as, "written era, radio era, TV era, online era, and the modern era whereas each of these generations has followed its predecessor so that now the world is using diverse yet viable systems of distance education which use all five generations as a combination (Anon., 2013). Thus, the education field is complex, diverse, and rapidly evolving (Anderson and Elloumi, 2004). Distance education has different meanings and often the term 'distance learning' is used without defining it (King et 
al., 2001). The United States Distance Learning Association described distance learning as the 'acquisition of knowledge and skills through mediated information and instruction, encompassing all technologies and other forms of learning at a distance' (King et al., 2001). It is a system of learning that uses electronic media, typically over the internet (Sangrà and González-Sanmamed, 2010) which includes distance learning and online education (Moore et al., 2011).

Online learning is a more recent version of distance education (Al-Arimi, 2014b) which improves access to educational opportunities for learners (Oliver, 2000) described as both non-traditional and disenfranchised manner (Moore et al., 2011). Additionally, technological advances have accelerated the development of educational materials for distance learning, offered through the Web (Tselios et al., 2001). According to the Sangrà and González-Sanmamed (2010) internet or information communication is providing mechanisms for fundamental changes in the education field.

Distance education is deemed as a promising invention of the education system with flexible learning environments (Allen et al., 2010). It is a field of education that focuses on new pedagogy/andragogy, technology, and instructional system design that are effectively incorporated in delivering education (AlArimi, 2014a). Informal learning will become more important in the future and this informal learning is strongly influenced by communication between peers which is a critical element of distance learning (Cross, 2006, as cited in Auvinen \& Smith, 2012). It provides benefits such as reducing education cost (Harrison and Lee, 2018) and ensuring the sustainability of education (Akinbadewa and Sofowora, 2020). Further it helps to provide lifelong learning opportunities for people (Alharthi, 2020). However, it is bound to some of the limitations such as unavailability of improved infrastructure and lack of awareness (Hebebci et al., 2020).

Nevertheless, there has been a substantial rise in use of such technologies in developing countries too, especially during COVID-19 period, whether it is language apps, virtual tutoring, video conferencing tools, or online learning software (Li and Lalani, 2020). Some of the scholarly work which focused on understanding the recent rise of online education due to Covid 19 pandemic found positive opinions about distance education as well as problems such as network issues, education and awareness (Arora and Srinivasan, 2020). Lall and Singh (2020) found, especially university undergraduates show a positive attitude towards online education due to flexible learning opportunities. Xie and Yang (2020) point out it as an opportunity to study independently at home during the pandemic while Hebebci et al. (2020) pointed out some students feel difficulty in finding a suitable study environment which affects continuity and effectiveness of paying attention to the academic work.

\section{The Role of Interaction in Online Learning}

Online learning is outlined as 'media to deliver, support, and enhance both learning and teaching and involves communication between learners and teachers utilizing online content' (Howlett et al., 2009). It gives advantages such as superior accessibility of information, cost-effectiveness, simplicity of standardizing and updating content which motivates an convenient learning environment (Wilson et al., 2006). Interaction in learning is outlined as dialogues which enables deep and reflective learning with the aim of achieving learning goals (Berge, 2002). The value of students' interactions with their instructors and peers has been continuously discussed in distance education literature (Wut and $\mathrm{Xu}$, 2021).

Interactivity is about success in communication and, in the context of online learning environments, one of the most crucial success factors. As a component of the humancomputer relationship or encounter communication, technology is used in education to enhance interactions between all participants in the educational service (Andersen and Garrison, 1998, Hedberg and Sims, 2001, Sims et al., 2002). Interaction is not simply a function of computer-based transactions, but a fundamental success factor for teaching and learning, especially when implemented in an online context (Sims et al., 2002). Interaction can also be delineated in 
terms of the actors participating in it. Michael Moore first discussed the three most common forms of interaction in distance education as 'student-student, student-teacher, and studentcontent' (Anderson and Elloumi, 2004).

Interaction in online learning environments is found to have a close positive relationship with students' higher order thinking and learners' interactions in large groups tremendously affect their epistemic emotions (Han et al., 2021). The quality of interaction between students and online content is one of the imperative factors in determining the efficacy of web-based teaching and leaning towards the creation and maintenance of sustainable learning communities (Ping, 2011). Student engagement is both a prerequisite and the result of a partnership. This complex phenomenon includes student participation, excitement, and persistence (Bovill et al., 2016). Educational institutions and universities should integrate and use their resources in such a way that student activities are integrated towards sustainability to promote mutual value creation among students (Monavvarifard et al., 2019).

Levine (2007) suggested some strategies for improving effective interactions in online education such as creating a positive and supportive learning environment, developing clear expected learning outcomes for activities within the course, providing necessary assistance by the teacher, recognizing students and teachers as co-creators of value and implementing activities which focus on higher order thinking, establishing multiple opportunities for participation, acknowledging individual students, contacting students who have disappeared from the discussion, and posing discussion questions which promote professional reflection and application to real world situations.

\section{Development an Infrastructure for Online Learning}

Every social system is built in a context. The social context of education in general has changed dramatically over the centuries. The increasingly open approach of education systems, supported by global village technologies carries education into the world. Therefore, every education institutions should consider the use of online technologies in the stages of planning and designing their mission, mandate, goals, and values etc (Davis et al., 2008a). Building infrastructure for distance education and online learning should be a priority which needs many interconnected components (Davis et al., 2008b). Access to computers, reliable internet connections, updated software rich with multimedia capability, microphones and cameras, facilities to improve technical expertise were recognized as key infrastructure for online education (Schroeder, 2001).

Education is one of the fastest-growing economic and social sectors in the world, and the use of new technologies is a key driver of this growth (McGreal and Elliott, 2008). Today's multimedia rich environment (text, graphic, audio, video, and animation) in internet enhances facilities in formal and informal online learning and teaching. Internet connection speeds or limit the quality and quantity of what can be transmitted. Even with wired/ wireless and high-speed advances the transmission of large sound, animation, and video files can be time-consuming and often frustrating (McGreal and Elliott, 2008). Therefore, especially the required infrastructure for online education should be developed to provide quality education facilities in distance mode. However, implementing e-learning in developing countries would be problematic due to infrastructure problems such as "economic conditions, facilities available, different educational backgrounds and pedagogical views, language and content issues, usability and technical literacy issues and attitudes and prejudice" (Tedre et al., 2010, p 9).

\section{Value Co-Creation in Education}

In the service-centered view, services are essentially characterized by being customercentric which is based on active customer participation (Lusch et al., 2007). Thus, the term value co-creation is often used to denote customer participation and engagement and posits that customers are active rather than passive (Ple and Cáceres, 2010). Co-creation of value is higher in services, particularly, in 'high involvement' services where customer and the service provider needs to interact with each other to develop a mutually valued 
outcome (Jayalath and Galdolage, 2021). Being a prominent service, education requires quality interactions between service provider (teacher) and the customer (student) to enhance the 'enjoyment of work' as well as 'value-inuse' which is the outcome of collaborative learning (Gallage et al., 2013).

Resource integration is the central practice of value co-creation and 'Operant resources' (skills, knowledge) are the "fundamental source of strategic benefit" (Vargo and Lusch, 2016:8). Operand resources are the resources on which an operation or act is executed to produce a result and are typically physical, such as raw materials or products (Vargo, 2008, Vargo and Lusch, 2004, Arnould et al., 2005). According to Galdolage (2021) and Mele (2011), the interactions between service providers' and customers' resources are essential in creating value. In the education sector, both operand (books, notes, assignments etc) and operant resources (skills, knowledge, abilities, ideas) belong to both parties (student and the teacher) should collaborate in the forms of interactions to create effective learning outcomes. However, it is needed to make sure whether the participants are enjoying the process (process enjoyment) of value co-creation (Kamalasena and Galdolage, 2020).

Service environment is another determinant of the quality of service delivery (Galdolage, 2015). It facilitates interactions by sharing resources that actors have with each other (Anderson and Elloumi, 2004). These interactions can be direct (e.g., person-toperson interactions) or indirect (e.g., interactions via appliances such as technology) (Plé and Cáceres, 2010). Therefore, this concept is applicable to study the online education context too. Value co-creation provides a personalized experience to customers (Monavvarifard et al., 2019) which is termed as 'value in-use' (Rihova et al., 2013).

In value co-creation service providers become 'value facilitators' who provide 'value propositions' to customers for their co-creation process. Here, the academics' (university teachers) role is to facilitate students' learning process by providing needed resources.
Customers are more active and need to collaborate in the value creation process (Vargo and Lusch, 2015). Thus, students' active engagement is expected to collectively increase value in education. Collaboration between mainly the teacher and the student decides the level of value creation as the outcome of education. However, scholarly work which recognized co-creation in teaching, particularly online education is very rare.

\section{Value Co-Destruction}

When considering the definitions of value codestruction, it can be viewed as the opposite phenomenon to the value co-creation. Value co-destruction happens when one party either service provider or the customer is unable to create the value appropriately. Therefore, cocreation depends on how adaptive actors are to the co-creation process (Kokko et al., 2018). It suggests that if one party is unable to adapt properly or interact with the service system and appropriately integrate resources, it causes failures in value co-creation (Fyrberg Yngfalk, 2013, p 1165). Academic literature suggests that value is not always co-created and shows the possibilities for actual or potential negative outcomes of interactions among actors (Ple and Cáceres, 2010). Ple and Cáceres (2010, p 431) define 'value co-destruction' as "an interactional process between service systems that results in a decline in at least one of the systems' well-being". Similarly, Terblanche (2014:7) viewed co-destruction as a "process by which value can be destroyed when two parties interact with each other to create value".

Value can also be co-destroyed during the interaction process, intentionally or accidentally (Echeverri and Skalen, 2011). Smith (2013) recognises value co-destruction due to the organisation's misuse of customers' resources whereas Laamanen and Skalen (2014) and Mele (2011) view co-destruction as a conflictual perspective of value co-creation. Thus, value co-destruction can be viewed as a tragedy (Cova and Paranque, 2016), a dark side of co-creation (Chowdhury et al., 2016) and also can coexist with value imbalances among interacting actors (Ple and Cáceres, 2010). An interaction could simultaneously result in value co-creation and value co- 
destruction (Vargo and Lusch, 2004). Gursoy et al. (2017) recognize disruptive customer behaviors as one of the reasons for customer value co-destructions. Chan et al. (2010) note that value co-creation as a double-edged sword, which results in co-creation to one party and co-destruction to another party. Echeverri and Skalen (2011) also recognized the duality of value outcomes of the same value practice which result in co-creation and co-destruction. According to them, value cocreation and co-destruction are key dimensions of the value practices, which depend on the expectations and perceptions of the parties and the situation and personal characteristics.

In the education field, value co-destruction can occur at the hands of both the students and the teacher. It may or may not be due to deficiency in the medium used for online learning and can occur during the learning process too. Although the student and the teacher properly contribute to the learning process, the potential for value co-destruction due to various issues such as technological problems.

\section{METHODOLOGY}

Since online education is new to Sri Lankan context, it is an underexplored area with lack of scholarly work. Exploratory research are typically carried out when the literature does not explain the phenomena appropriately or when the researcher needs to collect insights which hard to gather through quantitative methods (Sekaran and Bougie, 2016). Therefore, aligning with the research objectives which aims at exploring value cocreation and destruction in online education, this study was structured on qualitative methodology. Semi-structured interviews were conducted with some flexibility in probing to ensure the sufficiency and the quality of data collection (Rowley, 2012). Interviews were in the forms of face to face as well as over the phone and ranged from 30 to 45 minutes. An interview guide was prepared as the research instrument to make the interviewing process easy, efficient, and focused.

A non-probabilistic purposive sampling method was used in selecting participants. Accordingly, fifty (50) respondents (undergraduates) were interviewed representing different years in university education, different state sector universities, and diverse geographical locations in Sri Lanka. The study is limited to this sample size since information saturation is achieved (Palinkas et al., 2015).

The interviews were like friendly informal conversations, which motivated them to freely talk about the matter of interest. All the interviews were recorded with the permission of the respondents and transcribed into word documents. Data collection and analysis happened concurrently, such that the researcher transcribed and analyzed the completed interviews while continuing the data collection process. The data were analysed by means of 'thematic analysis' which is a method "for identifying, analysing, and reporting patterns (themes) within data" (Braun and Clarke, 2006:6).

\section{FINDINGS}

The study identified nine factors and grouped them into four key themes as resources availability, commitment, interaction, and the personal and domestic concerns which cause value co-creation to some respondents while causing value co-destruction to some others.

\section{Resource Availability}

The experiences that students received from online teaching differ from each other based on the availability of required resources. Respondents mainly point out the availability of appropriate devices (laptop computer, desktop computer or even a smartphone) and internet connection as significant in online learning. However, as the study found some of them do not have enough resources. As they mentioned, even though they have their own computer device, it happened to share with their siblings since school education is also taking place online in this period. Students who use smartphones to join online lessons pointed out their inability to see presentations clearly due to the small screen. Some of the students entertained with sufficient internet connection while some others complained about poor connectivity.

Connecting Device: All the respondents mentioned that they have a device either a desktop computer, laptop computer, tablet or a smart phone which can be used to get the 
ISSN 2738-2028 (Online) | Vol. 5 | No. 2 | 2021 July

online education facility. Even though some students did not have such devices at the beginning of online learning, they managed to buy or borrow and continue their studies. However, problems were recognized with the quality and suitability of the devices which lead unnecessary delays and difficulties. These disparities lead differences in value cocreation in online learning.

"I normally log from my own laptop and rarely use my smartphone otherwise I am going anywhere. When I use the laptop, I feel like I'm in the lecture and I can learn better than using a smartphone. Anyway, no matter for me with the device" (Value co-creation). (Final year student in Kurunegala)

I have a smartphone. It's hard because the screen is small. So, I can hardly see the presentations and it's like I'm just only listening. (Value co-destruction). (Final year student in Rathnapura).

Sometimes I have to share my phone with my brother. If both are having online sessions, one needs to sacrifice. So, I cannot properly learn in this new system. (Value co-destruction) (Second year student in Deniyaya).

Network coverage: Network Coverage is another key point of resource availability which result in inequalities in value cocreation. Some respondents experience sufficient and fast network coverage while some others are going through many difficulties in connecting to online lessons. It was recognized as largely varied with the geographic locations and however, some students in the western province also were recognized as having network coverage problems. Complaints are mainly on the reliability of the internet connections, slowness, and poor connectivity. Further, some students complain about persistent power failures which interrupt their connections. Following are the positive and negative experiences about the online based learning among university undergraduates when undergoing through different levels of internet coverage.

We have broadband to our house, and recently got the dialogue connection too. Anyway, we bought that special package for the zoom and MS teams. So, it is not a big issue for me. (Value co-creation (Third year student in Kandy)

I can't attend online lectures from home because I don't have enough signal coverage. It drops connection time to time. Most of the time I cannot attend the real time lectures. I used to collect notes and refer them later (Value co-destruction) (Final year student in Rathnapura)

In this area, power interruptions are very normal. It also disturbs a lot to my connections. (Value codestruction) (Second year student in Ududumbara)

\section{Commitment}

The study found, commitment of both the lecturer and the students, especially during this pandemic period determines the outcome of the academic activities. According to some of the respondents, they are not much interested in attending real-time online lectures, rather they collect uploaded lecture recordings and listen to them. Further, they said that they feel more flexibility in their schedules which lead prioritizing some other tasks assuming that they can refer to the recorded lectures when required. Following are the comments made on the commitment in online education in universities.

Student's Commitment: Though it happens online or offline, student commitment is essential for academic success. If they are committed, there can be many avenues to be successful. However, as we found some students inappropriately use the flexibility in online education prioritizing some other tasks.

At the beginning I also could not do it properly. But now it's a part of our daily life. So, I arranged a special convenient place in the living room and like in the university I do my regular work. (Value co-creation) (Third year student in Colombo)

Normally I do not like real time online lessons. They are not maintaining attendance. It uses more internet too. I 
ISSN 2738-2028 (Online) | Vol. 5 | No. 2 | 2021 July

know that the lecturer will upload the video later. So, collect, learn and watch leisurely. (Value codestruction) (Second year student in Gampaha).

However, the study found some incidents such as few of the students struggling with different commitments like householding work, financial commitments which make them deviate from focusing on education.

When I am Staying at university, I can pay attention to my studies well without attending to family issues. But when staying at home, I have to do something for them (financial commitments). I don't know how I can manage everything for such a long period. (Value co-destruction) (Second year student in Hambanthota).

Lecturer's Commitment: Commitment of the service provider is essential in any service provisions. If the teacher is not committed to such a teaching method, he/she may not be able to deliver his/ her service properly. Respondents share their view on how teachers' commitment motivates them to collaborate with online education.

They (lecturers) are very good. Well prepared. Send all the materials early to get ready. Conduct follow up sessions. The class itself is very live and interactive. It's very worth (Value co-creation) (Third year student in Badulla)

Sometimes I feel like not going to some lectures. It's like wasting time. Even though it is online they could have done it in an interesting way. It's very boring to see a screen for hours. One day, a video had played without sound for about fifteen minutes. We chatted and told him that we could not hear the sound. I do not know if the speaker was there at that time. (Value codestruction) (Final year student in Colombo)

\section{Interaction}

Whether attending an online-based lecture or attending a classroom-based lecture, interaction is a must and determine the level of co-creation or co-destruction of value. Interaction occurs face to face during a classroom-based lecture. In an online-based lecture it takes place from screen to screen. As the study found, and the literature describes (Anderson and Elloumi, 2004, Moore and Kearsley, 1996) interaction can take place in three forms. Student- Lecturer interaction, Student-Student interaction, and StudentContent interaction.

Student- Lecturer interaction: Most of the respondents pointed out that interaction with the lecturer is very minimal at the distancebased learning. However, some students used to ask questions and initiate discussion with the lecturer during the online teaching sessions. Even though good software and technologies are available that can be used to enhance student's engagement, the application of those mechanisms is minimal in online teaching.

I am normally talkative. If I have any question, I ask it. Normally I cannot keep it to solve later. Lecturers also appreciate when we ask questions. He (lecturer) also makes students talk somehow. He asks students to turn on the mic or the video and talk. Normally they give time for $Q$ and $A$. but most of the students are silent. (Value cocreation) (Second year student in Galle)

In the university we were very friendly with the lecturer. They give contact times. Any way we can meet them any time. But now we feel very isolated. Can't explain. But I feel like empty. (Value co-destruction) (Final year student in Nuwara Eliya)

Student-content interaction: Another way of university learning is student's interactions with the learning materials. That can be books, handouts, e-learning sources etc. According to respondents, some of the students are not properly interacting with the content.

I collect all the uploaded materials into folders, and also, I download some books to read. Because now we have enough time to read. (Value co- 
ISSN 2738-2028 (Online) | Vol. 5 | No. 2 | 2021 July

creation) (Third year student in Kurunegala)

I don't know what to do. There are lots of things I really want to do. But not like in past. Feeling very lazy. I used to work for deadlines. Now we don't know when the exams will be. So, I feel like I have no goals. It made me very idle. (Value co-destruction) (Second year student in Bandarawela)

Student-student interaction: Students are always getting together when they are on campus. They get many group activities, presentations which encourage their group behavior. Apart from that they have some informal events, get togethers too. As respondents mentioned, this new teachinglearning method restricts such interactions.

It's true. We cannot meet each other. But our lecturer groups us in the Zoom and gives some group activities. When we do take home assignments, she asks us to get to small groups as we wish. Then we can talk on WhatsApp, or phone and do it. We did two such assignments (Value co-creation) (Third year student in Gampaha)

Now we do not do any group events. Haven't seen them for ages. If I feel something difficult, I could have asked from friends in the university. But now I feel very bored without them. (Value codestruction) (Third year student in Badulla)

\section{Personal and Domestic Conditions}

Personal Circumstances such as mental and physical conditions of students as well as their household situations also recognized differently influence on students collaborative learning in online platforms

Personal Concerns: Adjusting to this new normal learning environment is not similarly easy for everybody. It is challenging to many students and requires them to change into a new lifestyle. The study found mental and physical conditions of students as well as capability in adjusting to new learning styles differently influence on the distance education output of the students.
This method is really easy for me. One thing is I do not want to go to university, which costs me more than 300 rupees a day. Since I started my internship, if I happened to go to campus, I might miss lectures. And after working for 8 hours at the office, studying another 2 hours till 8.30 is a bit tiring. But now I login to evening lessons even if I am in the office. It's actually a relief for me. (Value cocreation) (Final year student in Gampaha)

If I was in the hostel, internet free... I could do lots of things. Here we have time. But... without the internet we cannot do anything. I feel like...nothing to do... at least if they let us come to the hostel and join online lessons, it would be worth it. Now I am mentally down and don't know what will happen for my degree (Value codestruction) (Second year student in Matara)

Domestic Concerns: Education needs a free mind and calm environment. As we found, some students' household environment supports their education while some others are distracted by the surroundings. As few respondents mentioned, not having a suitable place, home responsibilities and family conflicts prevent them from co-learning at online platforms.

Actually, not like in the hostel. It's very calm and easy for me to do my work. I used to study in my room. No one disturbs me. Not like in the university. I don't want to go here and there to find food. For me. Its ok (Value co-creation) (Third year student in Matara)

It's bit disturbing. My brother is also doing online lessons at home. And my sister's children are playing and shouting. It's a small house and we do not have separate places to study. Difficult to concentrate (Value codestruction) (Second year student in Kaluthara)

\section{SUMMARY OF THE FINDINGS}


The aim of this study is to explore the reasons for value co-creation and co-destruction in distance learning (online education) among state sector university undergraduates in Sri Lanka. The findings show four key themes (reasons) which results in value co-creation to some students while result in co-destruction to others. The summary of the findings is given in the figure 1 below.

Reasons for Value co-creation and Value co-destruction in Online education

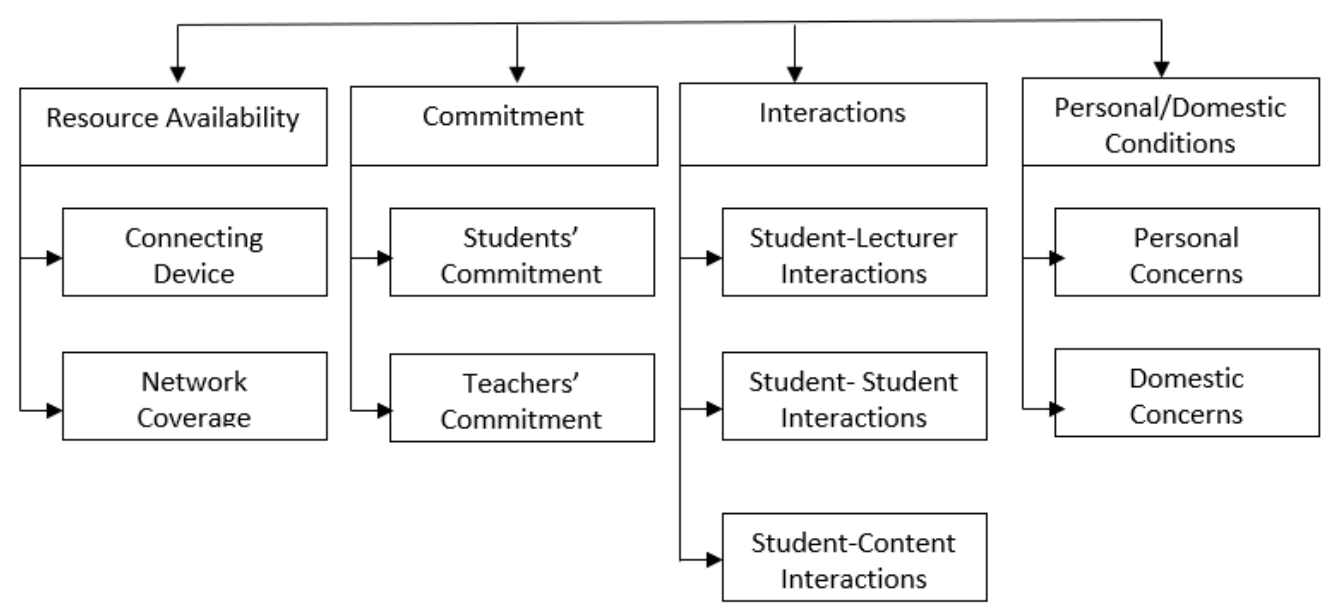

Figure 1: Factors determining value cocreation and co-destruction in online education for university undergraduates

Source: the authors

\section{DISCUSSION, RECOMMENDATIONS AND FUTURE RESEARCH DIRECTIONS}

This is a new phenomenon that the Sri Lankan higher education sector is experiencing from the recent past due to Covid 19 pandemic. Therefore, scholarly attention is very rare in this context. According to the study, experiences undergraduates received through online education differs from each other mainly due to resource availability. It mainly depends on the devices that they use to $\log$ in for online sessions and the network coverage. However, the commitment for the learning/ teaching of both the student and the lecturer is also recognized as very important. Interaction which takes place between the lecturer and students, among students and in between learning materials and students also play a significant role in online teaching. Further, personal as well as domestic conditions also result in positive as well as negative outcomes for students.
However, in developed countries information communication technology plays a large role in developing and delivering the learning content in higher education (Park, 2011). When providing such technology-based learning, e-learning infrastructure of a country becomes utmost important (Davis et al., 2008a). Students commitment on learning is essential when teaching is delivered in a remote platform (Simpson and Troost, 1982). Human-computer relationship or encounter communication technologies used in education to enhance interaction between all participants in the educational transaction (Sims et al., 2002). Interaction is not simply a function of computer-based transactions, but a fundamental success factor for teaching and learning, especially when implemented in an online context.

Michael Moore also discussed the importance of interaction among students, teachers and the resources (contents) in distance education (Anderson and Elloumi, 2004). Gosmire et al. (2009) identified learner-to-learner interaction as supportive of students' online learning. Further they found insignificant differences of learner-to-learner interaction with regard to gender, educational level, number of online courses that were taken, and the methods of 
feedback with the instructor. Some of the studies found problems related with online learning such as network issues, education and awareness (Arora and Srinivasan, 2020). Lall and Singh (2020) found a positive attitude towards online education due to flexible learning opportunities. Similarly, Xie and Yang (2020) recognize online education as an opportunity to study independently while Hebebci et al. (2020) pointed out difficulties such as finding an appropriate study environment. Interaction in online education is found to have a close positive relationship with students' higher order thinking (Han et al., 2021).

As theoretical contributions, this study fills the gap in the literature in distance education which is new and underexplored study area in Sri Lankan context. Further, it broadens the understanding of both the concepts of value cocreation and co-destruction in online education. As practical contributions, it provides the insights for policy makers, university academics as well as university students in optimizing collaborative value creation in online education.

This study is based on information obtained from 50 undergraduates chosen based on convenience. Therefore, it may not be enough to generalize these findings to the whole country's context. Further, the study found that the effectiveness of the online teaching is varying with geographic and demographic characteristics of the student. Therefore, there are avenues for future researchers to investigate social demographic variances related with distance education. Further, the distance education in schools also has greater potential for scholarly attention.

\section{Acknowledgement}

Authors would like to thank the anonymous reviewers for their excellent reviewer suggestions in completing this paper.

\section{Conflict of interest}

Authors declares no conflicts of interest.
Akinbadewa, B. O. \& Sofowora, O. A. 2020. The effectiveness of multimedia instructional learning packages in enhancing secondary school students' attitudes toward Biology. International Journal on Studies in Education (IJonSE), 2, 119-133.

Al-Arimi, A. 2014a. Distance Learning. Procedia - Social and Behavioral Sciences, 152.

Al-Arimi, A. M. A.-K. 2014b. Distance learning. Procedia-Social and Behavioral Sciences, 152, 82-88.

Alharthi, M. 2020. Students' Attitudes toward the Use of Technology in Online Courses. International Journal of Technology in Education, 3, 14-23.

Allen, B., Crosky, A., Yench, E., Lutze-Mann, L., Blennerhassett, P., Lebard, R., Thordarson, P. \& Wilk, K. 2010. A model for transformation: A trans-disciplinary approach to disseminating good practice in blended learning in science faculty. Curriculum, technology \& transformation for unknown future. Proceedings of ascilite Sydney, 36-48.

Andersen, T. \& Garrison, D. R. 1998. New roles for learners at a distance. In: GIBSON, C. \& MADISON, W. I. (eds.) Distance learning in higher education: Institutional responses for quality outcomes,. 2710 Atwood Avenue ,Madison, WI: Atwood Publishing.

Anderson, T. \& Elloumi, F. 2004. Theory and Practice of Online Learning. http://lstiiep.iiep-unesco.org/cgibin/wwwi32.exe//in=epidocl.in //?t2000 $=020568 /(100)$.

Anusudha, R. \& Krishnendu, R. 2021. Education at the Crossroads: Digitalization of Education in India During an Age of Pandemic. Psychology and Education Journal, 58, 1469-1479.

Arnould, E., xa, J, Thompson, C., xa \& J 2005. Consumer Culture Theory (CCT): Twenty Years of Research. Journal of Consumer Research, 31, 868-882.

\section{REFERENCES}


Arora, A. K. \& Srinivasan, R. 2020. Impact of pandemic COVID-19 on the teachinglearning process: A study of higher education teachers. Prabandhan: Indian journal of management, 13, 43-56.

Berge, Z. L. 2002. Active, interactive, and reflective elearning. The Quarterly Review of Distance Education, 3, 181190.

Blau, I. \& Shamir-Inbal, T. 2017. Re-designed flipped learning model in an academic course: The role of co-creation and coregulation. Computers \& Education, 115, 69-81.

Bovill, C., Cook-Sather, A., Felten, P., Millard, L. \& Moore-Cherry, N. 2016. Addressing potential challenges in cocreating learning and teaching: overcoming resistance, navigating institutional norms and ensuring inclusivity in student-staff partnerships. Higher Education, 71, 195-208.

Braun, V. \& Clarke, V. 2006. Using thematic analysis in psychology. Qualitative Research in Psychology, 3, 77-101.

Central Bank of Sri Lanka 2020. Annual report. Colombo: Central Bank of Sri Lanka.

Chan, K. W., Yim, C. K. \& Lam, S. K. 2010. Is Customer Participation in Value Creation a Double-Edged Sword? Evidence from Professional Financial Services Across Cultures. Journal of Marketing, 74, 48-64.

Chowdhury, I. N., Gruber, T. \& Zolkiewski, J. 2016. Every cloud has a silver lining Exploring the dark side of value cocreation in B2B service networks. Industrial Marketing Management, 55, 97-109.

Cova, B. \& Paranque, B. 2016. Brand Value Creation versus Destruction: The Relationship between Consumers, Marketers, and Financiers. Finance Reconsidered: New Perspectives for a Responsible and Sustainable Finance. Emerald Group Publishing Limited.
Davis, A., Little, P. \& Stewart, B. 2008a. Developing an Infrastructure for Online Learning. Theory and practice of online learning. 2 ed. Edmonton, AB: Athabasca University.

Davis, A., Little, P. \& Stewart, B. 2008b. Developing an infrastructure for online learning. Theory and practice of online learning, 97.

Echeverri, P. \& Skalen, P. 2011. Co-creation and co-destruction: A practice-theory based study of interactive value formation. Marketing Theory, 11, 351-373.

Erandi, K. K. W. H., Mahasinghe, A. C., Perera, S. S. N. \& Jayasinghe, S. 2020. Effectiveness of the Strategies Implemented in Sri Lanka for Controlling the COVID-19 Outbreak. Journal of Applied Mathematics, 2020, 2954519.

Fyrberg Yngfalk, A. 2013. 'It's not us, it's them!' - Rethinking value co-creation among multiple actors. Journal of Marketing Management, 29, 1163-1181.

Galdolage, B. 2015. Importance of services environment in changing consumer behavioral outcomes: Special reference to retail fashion brands in Sri Lanka. South Asian Journal of Marketing \& Management Research, 5, 56-66.

Galdolage, B. S. 2021. Customer Value CoCreation Intention, Practices and Experience in Self-Service Technologies. Journal of Scientific Research and Reports, 12-26.

Gallage, H., Galdolage, B. \& Rathnayaka, D. 2013. Workplace spirituality: a case of academics at state sector universities.

GlobeNewswire. 2021. research and markets [Online]. Available: https://www.globenewswire.com/news[Accessed].

Gosmire, D., Morrison, M. \& Van Osdel, J. 2009. Perceptions of interactions in online courses. MERLOT Journal of Online Learning and Teaching, 5, 609-617.

Gursoy, D., Cai, R. \& Anaya, G. J. 2017. Developing a typology of disruptive customer behaviors Influence of customer 
ISSN 2738-2028 (Online) | Vol. 5 | No. 2 | 2021 July

misbehavior on service experience of bystanding customers. International Journal of Contemporary Hospitality Management, 29, 2341-2360.

Han, Z.-M., Huang, C.-Q., Yu, J.-H. \& Tsai, C.-C. 2021. Identifying patterns of epistemic emotions with respect to interactions in massive online open courses using deep learning and social network analysis. Computers in Human Behavior, 122, 106843.

Harrison, T. R. \& Lee, H. S. 2018. iPads in the mathematics classroom: Developing criteria for selecting appropriate learning apps. International Journal of Education in Mathematics, Science and Technology, 6, 155-172.

Hebebci, M. T., Bertiz, Y. \& Alan, S. 2020. Investigation of views of students and teachers on distance education practices during the Coronavirus (COVID-19) Pandemic. International Journal of Technology in Education and Science (IJTES), 4, 267-282.

Hedberg, J. \& Sims, R. 2001. Speculations on design team interactions. Journal of Interactive Learning Research, 12, 193208.

Howlett, D., Vincent, T., Gainsborough, N., Fairclough, J., Taylor, N., Cohen, J. \& Vincent, R. 2009. Integration of a casebased online module into an undergraduate curriculum: what is involved and is it effective? E-Learning and Digital Media, 6, 372-384.

Jayalath, T. \& Galdolage, B. S. 2021. Customer Engagement in Private Sector Healthcare: How Does it Affect Customer Loyalty. Journal of Economics, Management and Trade, 30-40.

Kamalasena, B. \& Galdolage, B. 2020. Impact of Process Enjoyment in Value CoCreation on Customer Satisfaction in Wedding Planning in Sri Lanka.

Khlaif, Z. N., Salha, S., Fareed, S. \& Rashed, H. 2021. The hidden shadow of Coronavirus on education in developing countries. Online Learning, 25, 269-285.
King, F., Young, M., Richmond, K., Schrader, P. G. \& Kelly 2001. Defining distance learning and distance education. Educational Technology Review, 9.

Kokko, J., Vartiainen, T. \& Tuunanen, T. 2018. Value Co-Creation and CoDestruction in Online Video Games: An Exploratory Study and Implications for Future Research.

Laamanen, M. \& Skalen, P. 2014. Collectiveconflictual value co-creation: A strategic action field approach. Marketing Theory, $15,381-400$.

Lall, S. \& Singh, N. 2020. Covid-19: unmasking the new face of education. International Journal of Research in Pharmaceutical Sciences, 11, 48-53.

Levine, S. J. 2007. The online discussion board. New Directions for Adult and Continuing Education, 2007, 67-74.

Li, C. \& Lalani, F. 2020. The COVID-19 pandemic has changed education forever. This is how [Online]. World Economic Forum. Available: https://www.weforum.org/agenda/2020/0 4/coronavirus-education-global-covid19online-digital-learning/ [Accessed 10 April 2021].

Lusch, R. F., Vargo, S. L. \& O’Brien, M. 2007. Competing through service: Insights from service-dominant logic. Journal of Retailing, 83, 5-18.

McGreal, R. \& Elliott, M. 2008. Technologies of Online Learning (E-learning). In: ANDERSON, T. (ed.) Theory and practice of online learning. Edmonton, AB: Athabasca University.

Mele, C. 2011. Conflicts and value co-creation in project networks. Industrial Marketing Management, 40, 1377-1385.

Monavvarifard, F., Baradaran, M. \& Khosravipour, B. 2019. Factors Affecting Students' Value Co-creation to Institutionalize Sustainability in Academic Structure: The Case of Iranian Agricultural and Natural Resources' Universities. International Journal of 
Agricultural Management and Development, 9, 45-54.

Moore, J. L., Dickson-Deane, C. \& Galyen, K. 2011. e-Learning, online learning, and distance learning environments: Are they the same? The Internet and Higher Education, 14, 129-135.

Moore, M. G. \& Kearsley, G. 1996. Distance education: A system view, Wadsworth.

Oliver, M. 2000. Evaluating online teaching and learning. Information Services and Use, 20, 83-94.

Palinkas, L. A., Horwitz, S. M., Green, C. A., Wisdom, J. P., Duan, N. \& Hoagwood, K. 2015. Purposeful sampling for qualitative data collection and analysis in mixed method implementation research. Administration and policy in mental health, 42, 533-544.

Park, J. 2011. Design Education Online: Learning Delivery and Evaluation. International Journal of Art \& Design Education, 30, 176-187.

Ping, T. 2011. Students' Interaction in the Online Learning Management Systems: A Comparative Study of Undergraduate and Postgraduate Courses. Asian Association of Open Universities Journal, 6, 59-73.

Ple, L. \& Cáceres, C. 2010. Not always cocreation: introducing interactional codestruction of value in service-dominant logic. Journal of Services Marketing, 24, 430-437.

Plé, L. \& Cáceres, R. 2010. Not always cocreation: introducing interactional codestruction of value in Service-Dominant Logic. Keywords. Journal of Services Marketing, 24, 430-437.

Rihova, I., Buhalis, D., Moital, M. \& Beth Gouthro, M. 2013. Social layers of customer-to-customer value co-creation. Journal of Service Management, 24, 553566.

Rowley, J. 2012. Conducting research interviews. Management Research Review, 35, 260-271.
Sangrà, A. \& González-Sanmamed, M. 2010. The role of information and communication technologies in improving teaching and learning processes in primary and secondary schools. ALT-J, 18, 207-220.

Schroeder, R. 2001. Institutional support infrastructure for online classes. Metropolitan Universities, 12, 35-40.

Sekaran, U. \& Bougie, R. 2016. Research Methods For Business: A Skill Building Approach, Wiley.

Simpson, R. D. \& Troost, K. M. 1982. Influences on commitment to and learning of science among adolescent students. Science Education, 66, 763-781.

Sims, R., Dobbs, G. \& Hand, T. 2002. Enhancing Quality in Online Learning: Scaffolding Planning and Design Through Proactive Evaluation. Distance Education, 23, 135-148.

Smith, A. 2013. The value co-destruction process: a customer resource perspective. European Journal of Marketing, 47, 18891909.

Tedre, M., Ngumbuke, F. \& Kemppainen, J. 2010. Infrastructure, human capacity, and high hopes: A decade of development of e-Learning in a Tanzanian HEI. RUSC. Universities and Knowledge Society Journal, 7, 7-20.

Terblanche, N. S. 2014. Some theoretical perspectives of co-creation and coproduction of value by customers.

Tselios, N., Avouris, N., Dimitracopoulou, A. \& Daskalaki, S. 2001. Evaluation of Distance-Learning Environments: Impact of Usability on Student Performance. International Journal of Educational Telecommunications, 7, 355-378.

University Grants Commission. 2021. Universities and Higher Educational Institutions established under the purview of the University Grants Commission [Online]. Sri Lanka: University Grants Commission. Available: https://www.ugc.ac.lk/index.php?option= 
ISSN 2738-2028 (Online) | Vol. 5 | No. 2 | 2021 July

com_university \&view=list \&Itemid $=25 \& 1$ ang=en [Accessed].

Vargo, S. \& Lusch, R. 2015. Institutions and axioms: an extension and update of service-dominant logic. Journal of the Academy of Marketing Science, 44.

Vargo, S. L. 2008. Customer Integration and Value Creation: Paradigmatic Traps and Perspectives. Journal of Service Research, 11, 211-215.

Vargo, S. L. \& Lusch, R. F. 2004. Evolving to a New Dominant Logic for Marketing. Journal of Marketing, 68, 1-17.

Vargo, S. L. \& Lusch, R. F. 2016. Institutions and axioms: an extension and update of service-dominant logic. Journal of the Academy of Marketing Science, 44, 5-23.

Wilson, A., Goodall, J., Ambrosini, G., Carruthers, D., Chan, H., Ong, S., Gordon, C. \& Young, S. 2006. Development of an interactive learning tool for teaching rheumatology - a simulated clinical case studies program. Rheumatology, 45, 11581161.

Wut, T.-m. \& Xu, J. 2021. Person-to-person interactions in online classroom settings under the impact of COVID-19: a social presence theory perspective. Asia Pacific Education Review, 1-13.

Xie, Z. \& Yang, J. 2020. Autonomous learning of elementary students at home during the COVID-19 epidemic: A case study of the Second Elementary School in Daxie, Ningbo, Zhejiang Province, China. Ningbo, Zhejiang Province, China (March 15, 2020). 